\title{
CRIMES AMBIENTAIS: PRINCÍPIOS E EVOLUÇÃO
}

Lucas Daniel Ferreira de Souza

ISSUE DOI: $10.21207 / 1983.4225 .232$

\section{RESUMO}

Atualmente o mundo gira em torno de uma economia ambiciosa, onde cada vez mais o ser humano e especialmente as pessoas jurídicas se valem do meio ambiente para atender a inescrupulosa demanda por bens materiais. Esta ação desenfreada e sem planejamento algum, vem pondo em risco nossa natureza e prejudicando a qualidade de vida das gerações presentes e futuras. Destarte o presente artigo aborda os principais pontos em torno do meio ambiente como bem jurídico tutelado, debatendo acerca de sua evolução no ordenamento jurídico pátrio e os princípios que o norteiam. O texto reveste-se de caráter panorâmico ao investigar o Meio Ambiente como bem jurídico de cunho material no Estado Democrático de Direito.

Palavras-Chave: Meio Ambiente. Evolução. Crimes. Pessoa Jurídica.

\section{INTRODUÇÃO}


Atualmente a degradação ambiental tem atingido níveis alarmantes e a destruição da flora vem, consequentemente, provocando a morte e a extinção de inúmeras espécies. Foi com o advento da Revolução Industrial que começaram efetivamente as agressões ao ecossistema, pois com o êxodo rural, os centros urbanos cresceram de forma desmedida sem nenhum planejamento o que, aliado ao fenômeno da industrialização, trouxe fortes agressões ao meio ambiente e a uma sadia qualidade de vida.

Não paira dúvida alguma sobre a real necessidade de se estabelecer uma proteção adequada e eficiente para impedir a crescente degradação da natureza, tanto é verdade que inúmeras legislações, de diversos países, têm elevado o meio ambiente à categoria de bem juridicamente protegido. No Brasil, essa tendência mundial não poderia ter sido diferente. $\mathrm{O}$ ordenamento jurídico brasileiro, em se tratando de matéria ambiental, sempre se mostrou fraco e ultrapassado, aplicando sanções pouco severas aos delitos praticados contra a fauna e a flora e demonstrando falta de eficácia na aplicação dessas. A exemplo de leis ambientais, temos a Lei n 4.771/65 (Código Florestal), a Lei n 5.197/67 (Código de Caça) e a Lei ${ }^{\circ}$ 6.938/81 (que trata sobre a Política Nacional do Meio Ambiente). Já a vigente Constituição Federal de 1988 trouxe, em seus artigos 173 $\S 5^{\circ}$ e $225 \S 3^{\circ}$, a Responsabilidade Penal das Pessoas Jurídicas pelo cometimento de delitos ambientais.

Posteriormente, com o advento da "Lei de Crimes Ambientais", Lei $n^{\circ} 9.605$ de 12 de fevereiro de 1998, foi que efetivamente se previu, pela primeira vez no ordenamento jurídico brasileiro, sanções penais e administrativas às condutas lesivas das pessoas jurídicas ao meio ambiente.

Apesar de controvertida a matéria acerca da responsabilidade penal das pessoas jurídicas frente aos crimes ambientais, algo é certo: o legislador, ao criar a Lei de Crimes Ambientais procurou, baseado em leis de outros países, trazer o que há de mais moderno para a proteção do meio ambiente, demonstrando, assim, a preocupação do homem em preservar e proporcionar segurança, dignidade e bem-estar não só à geração presente, como também para garantir tais qualidades às gerações vindouras. 
Tudo que está em volta de alguma pessoa ou coisa é ambiente. A expressão indica tudo que envolve ou cerca as coisas ou os seres vivos, por todos os lados. Por sua vez, meio é o lugar onde se vive. Portanto, observa-se um pleonasmo, visto que o conceito de ambiente está inserto no conceito de meio, sendo assim, é desnecessária tal redundância, porém a explicação para a terminologia estar consagrada na doutrina, na jurisprudência e na própria consciência da população, é tão somente o objetivo de realçar, dar ênfase, a esse bem jurídico, sem o qual não sobreviveríamos. $^{208}$

O Direito Brasileiro, expressamente, conceitua o meio ambiente na "Lei da Política Nacional do Meio Ambiente", Lei n 6.938 de 31 de agosto de 1981, definindo em seu artigo $3^{\circ}$, § I como sendo "o conjunto de condições, leis, influências e interações de ordem física, química e biológica, que permite, abriga e rege a vida em todas as suas formas".

Na definição de José Afonso da Silva, "o meio ambiente é, assim, a interação do conjunto de elementos naturais, artificiais e culturais que propiciem o desenvolvimento equilibrado da vida em todas as suas formas". ${ }^{209}$

O egrégio Supremo Tribunal Federal, no julgamento do Mandado de Segurança n. ${ }^{\circ} 22.164$ acontecido em 17 de novembro de 1995, em que foi relator o eminente Ministro Celso de Mello, deu ao conceito de meio ambiente a extensão de direito fundamental de toda uma coletividade social, nos seguintes termos:

A questão do direito ao meio ambiente ecologicamente equilibrado - direito de terceira geração - princípio da solidariedade.

$\mathrm{O}$ direito à integridade do meio ambiente - típico direito de terceira geração - constitui prerrogativa jurídica de titularidade coletiva, refletindo, dentro do processo de afirmação dos direitos humanos, a expressão significativa de um poder atribuído, não ao indivíduo identificado em sua singularidade, mas,

\footnotetext{
${ }^{208}$ MATEO, Ramón Martín. Derecho Ambiental. Instituto de Estudio de Administración Local. Madrid, 1997. p. 71.

${ }^{209}$ SILVA, José Afonso da. Direito Ambiental Constitucional. 2 ed. São Paulo: Malheiros, 1995. p. 02.
} 
num sentido verdadeiramente mais abrangente, à própria coletividade social.

Enquanto direitos de primeira geração (direitos civis e políticos) - que compreendem as liberdades clássicas, negativas ou formais - realçam o princípio da liberdade e os direitos de segunda geração (direitos econômicos, sociais e culturais) - que se identificam com as liberdades positivas, reais ou concretas - acentuam o princípio de igualdade, os direitos de terceira geração, que materializam poderes de titularidade coletiva atribuídos genericamente a todas as formações sociais, consagram o princípio da solidariedade e constituem um momento importante no processo de desenvolvimento, expansão e reconhecimento dos direitos humanos, caracterizados, enquanto valores fundamentais indisponíveis, pela nota de uma essencial inexauribilidade. Considerações doutrinárias (DJU, Seç. 1, de 17-11-95, p. 39.206).

Dessa forma, pode-se definir meio ambiente como sendo o conjunto no qual o homem está inserido, dele dependendo para se preservar, tanto no sentido de proporcionar bem-estar, segurança e dignidade, quanto no sentido de sobreviver social, espiritual e biologicamente.

\section{$1.1 \quad$ Espécies de meio ambiente}

O conceito de meio ambiente é muito mais amplo, pois abrange todos os bens naturais, sociais, artificiais e culturais de valor jurídico, desde o ar, flora, solo, as águas, as belezas naturais e artificiais. Considera-se meio ambiente o conjunto de condições sociais, naturais e culturais onde vive o ser humano e que influenciam a sua existência. ${ }^{210}$

Assim o meio ambiente é dividido em: meio ambiente natural, meio ambiente artificial, meio ambiente cultural e meio ambiente laboral. 


\subsubsection{Meio ambiente natural}

O meio ambiente natural ou também chamado de físico, é constituído pelos recursos naturais (solo, água, ar, fauna, flora, biodiversidade e biotecnologia) e pela correlação de cada um destes elementos com os demais. $^{211}$

\subsubsection{Solo}

O termo "solo" é utilizado em dois sentidos: solo, como espaço social, e solo, como recurso natural. Solo como recurso natural é a relação entre a preservação do solo e a qualidade ambiental, isso se explica pelo fato de animais e vegetais dependerem disso para a sua subsistência. Assim sendo, a exploração inadequada do solo gera consequências gravíssimas ao meio ambiente, modificando a vida dos seres vivos que ali habitam ou até causando sua extinção.

Solo como espaço social está ligado justamente ao ambiente onde o ser humano habita, principalmente nas cidades, onde se verifica os prejuízos causados pela exploração inadequada do solo, que com o crescimento e desenvolvimento da cidade, ocupam áreas que não deveriam ser ocupadas, isso tudo se dá pela falta de estudo prévio de impacto ambiental. $^{212}$

A Constituição Federal de 1988 estabelece que a proteção do meio ambiente é de competência da União, dos Estados, do Distrito Federal e dos Municípios, prevendo ainda competência concorrente desses, com exceção do Município, para legislar sobre a questão da defesa do solo, proteção do meio ambiente e controle da poluição, ressaltando a competência suplementar dos municípios.

O artigo 186, II da Constituição Federal de 1988 é muito claro quando trata da função social da propriedade rural, estabelecendo que a função social é cumprida com o seu aproveitamento racional e adequado, com a utilização adequada dos recursos naturais disponíveis e preservação do meio ambiente, observância das disposições que regulam as rela-

\footnotetext{
${ }^{211}$ LEMOS, Patrícia Fraga Iglecias. Direito Ambiental: Responsabilidade Civil e Proteção ao Meio Ambiente. p. 28.

${ }^{212}$ Idem. p. 30.
} 
ções de trabalho e a exploração que favoreça o bem estar dos proprietários e dos trabalhadores, sendo que, a não obediência à função social da propriedade rural autoriza a União a desapropriar o imóvel rural para fins de reforma agrária, mediante prévia e justa indenização em títulos da dívida agrária, com cláusula de preservação do valor real, resgatáveis no prazo de até vinte anos, a partir do segundo ano de sua emissão, e cuja utilização será definida em lei (artigo 184 da Constituição Federal de 1988).

A Constituição Federal de 1988 em seu artigo 182 estabelece que a propriedade urbana cumpre a sua função social quando atende as exigências fundamentais de ordenação da cidade expressas no plano diretor, sendo que a sua inobservância permite a desapropriação, com pagamento mediante títulos da dívida pública de emissão previamente aprovada pelo Senado Federal, com prazo de resgate de até dez anos, em parcelas anuais, iguais e sucessivas, assegurados o valor real da indenização e os juros legais.

\subsubsection{2 Água}

A água pode ser definida como uma substância composta por dois átomos de hidrogênio e um de oxigênio, constituinte fundamental da matéria viva e do meio que a condiciona.

A água é um bem insuscetível de apropriação privada, pois é indispensável à vida humana, animal e vegetal, sendo que a legislação faz distinção entre águas de domínio particular e águas de domínio público.

A importância da água é indiscutível, pois além de suas funções biológicas e bioquímicas, ela é parte integrante da cadeia alimentar e de processos biológicos, Porém, é importante ressaltar que apesar de falarmos da água em sentido amplo, ou seja, água doce e salgada, a porcentagem de recursos hídricos disponíveis é muito pequena, apenas cerca de $2,7 \%$ da água do planeta é de água doce, e somente $0,40 \%$ é encontrada nas águas continentais superficiais e na atmosfera, sendo que $22,4 \%$ de toda massa hídrica são águas subterrâneas. ${ }^{213}$

\footnotetext{
${ }^{213}$ LEMOS, Patrícia Fraga Iglecias. Direito Ambiental: Responsabilidade Civil e Proteção ao Meio Ambiente. p. 30.
} 
Os artigos 20 e seguintes da Constituição Federal de 1988 estabelecem que são de propriedade da União: os lagos, os rios e as correntes de águas existentes em terrenos de seu domínio, que banhem mais de um Estado, que sejam limites com outros países e que se estendam a território estrangeiro ou dele provenham. São bens do Estado: as águas superficiais ou subterrâneas, fluentes, emergentes e em depósito, excluindo-se as decorrentes de obra da União, conforme determinar a lei, também são de domínio da União: o mar territorial, os recursos naturais da plataforma continental e da zona econômica exclusiva.

A Constituição Federal de 1988 no artigo 21, XII, b, estabelece que a competência é da União para explorar diretamente ou mediante autorização, concessão ou permissão dos serviços e instalações de energia elétrica e o aproveitamento energético dos cursos de água, em articulação com os Estados onde se situam os potenciais hidroenergéticos, e no artigo 22, IV, fixa a competência privativa da União para legislar sobre águas e energia.

\subsubsection{Ar atmosférico}

O ar atmosférico é um recurso natural que é "protegido" pela lei. O Código Penal no artigo 252 fixa pena para quem expuser a perigo de vida, a integridade física ou patrimonial de outrem, com gás tóxico ou asfixiante, (pena de reclusão de 1 a 4 anos e multa); além desse dispositivo, o Decreto Lei $n^{\circ} 3.688 / 41$ (Lei das Contravenções Penais) também resguarda a qualidade do ar atmosférico citando em seu artigo 38, sanção para o agente que provocar abusivamente da emissão de fumaça, vapor ou gás que possa molestar alguém.

$\mathrm{O}$ ar atmosférico é de suma importância para os processos vitais dos seres vivos, principalmente na respiração e na fotossíntese e é um recurso natural que se contamina facilmente e rapidamente, porém, da mesma forma, existindo condições favoráveis, pode ser recuperado facilmente. $^{214}$

\footnotetext{
${ }^{214}$ LEMOS, Patrícia Fraga Iglecias. Direito Ambiental: Responsabilidade Civil e Proteção ao Meio Ambiente. p. 33.
} 
O ar atmosférico poluído causa alteração nas características biológicas, físicas e químicas normais da atmosfera, causando danos aos seres vivos e ao seu respectivo habitat.

Considerando a gravidade do problema do ar, faz-se necessário a intervenção e a adoção de medidas para o controle de atividades poluidoras para se obter melhores condições de vida para a população, principalmente das grandes regiões metropolitanas, onde se deveria a todo momento realizar o monitoramento da qualidade do ar.

Existem dois programas nacionais que buscam garantir e controlar a qualidade do ar, criados por resoluções do CONAMA: $1^{\circ}$ ) o Programa Nacional de Controle do Ar por Veículos Automotores - Proconve - Resolução 18 do CONAMA de 6/5/1986, que visa reduzir e regular as emissões; $2^{\circ}$ ) o Pronar (Programa Nacional de Controle da Qualidade do Ar) Resolução 5 do CONAMA de 15/7/198 9. Pode ser citado ainda a Resolução 3 do CONAMA de 28/6/1990 que versa sobre a concentração de poluentes atmosféricos; Resolução 8 do CONAMA de 6/12/1990, que trata dos limites máximos de emissão de poluentes do ar; e por fim, a Lei $n^{\circ} 10.203$ de 22/2/2001, que gerou nova interpretação aos artigos $9^{\circ}$ e 13 da Lei $n^{\circ} 8.273$ de 28/1/1993, que versa sobre a redução da emissão de poluentes por veículos automotores e dá outras providências.

Importante também é a questão da camada de ozônio, à qual a Portaria 534 do Ministério da Saúde de 19/9/1988, proibia a comercialização de produtos sob a forma de aerossóis com propelentes à base de clorofluorcarbonos. Temos ainda, a resolução do CONAMA 267/2000 que versa sobre a proibição de substâncias que destroem a camada de ozônio; e a Resolução 340/2003 também do CONAMA que trata da utilização de cilindros para o envasamento de gases que destroem a camada de ozônio.

\subsubsection{Flora}

A flora pode ser definida como a totalidade de espécies vegetais que compreendem a vegetação de uma determinada região, englobando também bactérias, fungos e fitoplânctons marinhos, porém, a visão de flora deve ser mais ampla, considerando a sua importância na relação entre elementos bióticos e abióticos, levando-se em conta ser ela um todo, de forma a considerá-la como um ecossistema que engloba árvores, mas 
não tão somente isso, abrangendo também água e solo, animais e microorganismos, ou seja, todos os vegetais e elementos que compartilham das mesmas qualidades ecológicas e ambientais. ${ }^{215}$

Em suma, alguns dos grandes problemas encontrados quando o assunto é flora, é a sua preservação, isso se explica pela ocorrência frequente e degenerada de queimadas, desmatamentos, minerações etc.

Nesse sentido, existem algumas normas que tentam inibir essas atividades visando a preservação, as quais é possível citar: o Código Florestal, Lei no 4.771 de 15/9/1965; o Decreto Lei no 2.119 de 13/1/1997, que versa sobre o Programa Piloto para a proteção das florestas tropicais do Brasil e sobre a sua comissão de coordenação e dá outras providências, etc.

\subsubsection{Fauna}

A fauna pode ser definida como o conjunto de animais que habitam determinado local ou ambiente e possuem relação direta com a floresta existente.

Um dos problemas encontrados quando o assunto é a fauna, é o da caça e pesca predatória, que como consequência gera a diminuição da biodiversidade e o desequilíbrio na cadeia alimentar, e como efeito posterior, institui o risco de extinção de determinadas espécies. ${ }^{216}$

O artigo 225, § $1^{\circ}$, VII, da Constituição Federal de 1988, versa sobre a proteção da fauna, proibindo determinadas condutas que coloquem em risco a sua função ecológica, o que inclui a aplicação de pesticidas, o desmatamento, bem como a destruição de determinado habitat, proibindo também as práticas que provoquem a extinção das espécies e que submetam os animais à crueldade.

Importante ressaltar que a fauna silvestre é a que tem exigido maiores preocupações por ser a mais ameaçada, podendo citar aqui os animais não domesticados, do conjunto de vertebrados, algumas espécies de peixes por causa de suas características, mamíferos, aves, etc.

\footnotetext{
${ }^{215}$ LEMOS, Patrícia Fraga Iglecias. Direito Ambiental: Responsabilidade Civil e Proteção ao Meio Ambiente. p. 35.

${ }^{216}$ Idem. p. 36.
} 
Inúmeras leis visam proteger a fauna, dentre elas é possível citar: a Lei no 7.679 de 23/11/1988, que versa sobre a proibição da pesca de espécies em períodos de reprodução e dá outras providências; O Código de Pesca, Decreto Lei $n^{\circ} 221$ de 28/2/1967, que trata da proteção e estímulos à pesca; o Código de Caça, Lei no 5.197 de 3/1/1967, que dispõe sobre a proteção à fauna.

\subsubsection{Biodiversidade e biotecnologia}

A biodiversidade pode ser definida como uma grande variedade de genes, espécies vivas e diferentes ecossistemas, pois dentro dos ecossistemas são desenvolvidas relações entre espécies e a interação dos elementos nele presentes.

A biodiversidade possui patrimônio genético muito rico, encontrando-se conceitos de genoma (composição genética total de um ser vivo) e de germoplasma (conjunto de elementos genéticos voltados a perpetuar a espécie viva com todas as suas características). ${ }^{217}$

O artigo 225 da Constituição Federal de 1988 versa sobre a proteção da biodiversidade e dos ecossistemas; além disso, a legislação esparsa cuida ainda da proteção da fauna, flora e também de ecossistemas específicos, como é o caso da Mata Atlântica, que é protegida pelo Decreto Lei $\mathrm{n}^{\circ} 750 / 93$.

$\mathrm{O}$ artigo $2^{\circ}$ da Convenção de Biodiversidade traz a definição de Biotecnologia: "Biotecnologia é qualquer aplicação tecnológica que utilize sistemas biológicos, organismos vivos, ou seus derivados, para fabricar ou modificar produtos ou processos para a utilização específica".

O tema biotecnologia é bem amplo, porém o que traz mais questionamentos, dúvidas, críticas, é a questão que se refere ao genoma humano e a clonagem: se por um lado tais pesquisas podem ajudar a cura de doenças , reprodução de órgãos e organismos, por outro lado podem interferir no curso natural da vida, através da clonagem e a reprodução artificial de uma vida.

\footnotetext{
${ }^{217}$ LEMOS, Patrícia Fraga Iglecias. Direito Ambiental: Responsabilidade Civil e Proteção ao Meio Ambiente. p. 38.
} 


\subsubsection{Meio ambiente artificial}

Meio ambiente artificial pode ser definido como o espaço urbano construído, conjunto de edificações, espaço ocupado pelas construções, ruas, avenidas, praças e demais ambientes que foram modificados pela interferência do homem, inclusive áreas rurais, como por exemplo, uma plantação de café. ${ }^{218}$

Antes de 1988, como o Brasil não tinha uma política clara de desenvolvimento urbano, as áreas urbanas foram ocupadas de maneira desordenada. A Constituição Federal de 1988 implantou, no seu artigo 182 a política que deveria ser seguida pelo poder público municipal, o qual deve seguir as diretrizes gerais fixadas em lei (Lei $\mathrm{n}^{\circ}$ 10.257/2001 Estatuto da Cidade) de forma a ordenar o pleno desenvolvimento das funções sociais da cidade e garantir o bem-estar dos seus habitantes.

A Lei ${ }^{\circ} 10.257 / 2001$ é uma norma de direito urbanístico, voltada para fixar normas para o uso adequado da propriedade urbana, obedecendo assim a função social da propriedade urbana, que considera, além dos interesses do proprietário, os interesses da coletividade.

\subsubsection{Meio ambiente cultural}

A importância do meio ambiente cultural também é inquestionável, por esse motivo a legislação lhe concerne proteção, isso pode ser verificado no artigo 216, "caput" da Constituição Federal de 1988, que em seu texto considera como patrimônio cultural brasileiro os bens de natureza material e imaterial, tomados individualmente ou em conjunto, portadores da referência à identidade, à ação, à memória dos diferentes grupos formadores da sociedade brasileira, nos quais se incluem: I - as formas de expressão; II - os modos de criar, fazer e viver; III - as criações científicas, artísticas e tecnológicas; IV - as obras, objetos, documentos, edificações e demais espaços destinados às manifestações artístico-culturais; V - os conjuntos urbanos e sítios de valor histórico, paisa-

\footnotetext{
${ }^{218}$ LEMOS, Patrícia Fraga Iglecias. Direito Ambiental: Responsabilidade Civil e Proteção ao Meio Ambiente. p. 39.
} 
gístico, artístico, arqueológico, paleontológico, ecológico, científico, etc. $^{219}$

\subsubsection{Meio ambiente laboral}

Meio ambiente laboral pode ser entendido como o espaço onde se é desenvolvida a atividade laboral, comportando todas as condições para o bom desenvolvimento da produção, respeitando-se a dignidade da pessoa humana. $\mathrm{O}$ artigo $7^{\circ}$ da Constituição Federal de 1988 garante os direitos do trabalhador, sendo que alguns deles possuem relações diretas com o meio ambiente laboral, como por exemplo, o inciso XXII do referido artigo, que dispõe da redução dos riscos inerentes ao trabalho, por meio de normas de saúde, higiene e segurança; o XXIII, que trata da remuneração para as atividades insalubres ou perigosas; o XXXIII, que proíbe o trabalho noturno, perigoso ou insalubre a menores de 18 anos, etc. O artigo 114 da Constituição Federal de 1988 confere a competência à justiça do trabalho quando o assunto for atinente ao meio ambiente laboral. $^{220}$

\section{EVOLUÇÃO HISTÓRICA}

Desde os primórdios é possível verificar resquícios de uma responsabilização coletiva, para melhor compreensão e correlação com a responsabilidade penal dos entes coletivos, faz-se mister aprofundarmonos nas elaborações normativas outrora aplicadas.

Na Babilônia, onde vigorava o Código de Hamurabi, tal ordenamento penalizava as cidades onde ocorriam determinados delitos. Um exemplo que evidencia essa informação consta no parágrafo 23 desse Código, no qual se de algum indivíduo fosse subtraído algo e após as diligências que de praxe eram feitas não fosse nada recuperado, caberia ao governante ou à cidade onde ocorreu o evento lhe ressarcir pelos objetos furtados ou roubados.

\footnotetext{
${ }^{219}$ LEMOS, Patrícia Fraga Iglecias. Direito Ambiental: Responsabilidade Civil e Proteção ao Meio Ambiente. p. 40.

${ }^{220}$ Idem. p. 41.
} 
O Direito Romano reconhecia a existência das pessoas jurídicas e até mesmo chegou a regulamentá-la através da Lei das XII Tábuas. Apesar de evidente sua existência, alguns doutrinadores ainda pecam em defenderem que tal questão não existia no direito romano. O Direito Romano ao disciplinar os direitos, as obrigações, os delitos e as penas aplicáveis às pessoas jurídicas, fez, sem dúvida, uma das maiores contribuições ao estudo em exame.

No Direito Hebreu, que se baseava na Bíblia como Carta Magna, as punições passavam do apenado, sendo aplicadas também à entidade familiar do criminoso até o quarto grau parental.

$\mathrm{Na}$ Índia, a legislação que vigora se baseava no Código de Manu. Nessa sociedade também podemos notar um resquício de responsabilização coletiva, visto que se um Brahmana prestasse falso testemunho, não só esse, mas toda a sua família teria como punição, a morte.

No Japão, bem como na China, a responsabilização por delitos como traição, atentado contra a vida do imperador e até a falta de registro público dos bens que tivesse, a citar esses exemplos, poderia acarretar sanções não só a quem praticou tal delito, mas também a sua família, principalmente aos parentes de primeiro grau em linha reta do criminoso.

Pode-se dizer que o Direito canônico foi o primeiro a diferenciar as corporações de seus membros. E fez isso com fundamento de que os direitos não pertencem a seus fiéis, mas sim a Deus. Os canonistas começaram a criar um conceito técnico-jurídico de pessoa jurídica. Partem da aceitação da capacidade jurídica da universalidade, separada da capacidade jurídica dos seus membros. Passa-se a sustentar que os titulares dos direitos eclesiásticos não são os membros da comunidade religiosa, mas Deus, na figura de seu representante terrestre. Aparece aqui, a distinção entre o conceito jurídico de pessoa e conceito real de pessoa como ser humano. Esse rompimento da identificação entre a corporação eclesiástica e a pessoa como ser humano dá origem ao conceito de pessoa jurídica que, por ficção jurídica, passa a ter capacidade jurídica.

O Direito Muçulmano que é regido pelo Alcorão prevê, além da responsabilidade individual, a responsabilidade familiar, na qual podemos traduzir para responsabilidade coletiva, visto que, se um homicídio é cometido, o patriarca da vítima tem o direito de procurar a família do acusado para que estes venham a indenizar aqueles.

O Direito Germânico inicialmente vale-se da teoria da ficção de Savigny, para posteriormente considerar as sanções penais aos entes cole- 
tivos. Com essa alteração, sustentavam os juristas daquela época que, se a irresponsabilidade desses entes perdurasse, isso constituiria um grande perigo, visto que esses dispunham de mais poder que um simples cidadão.

O Direito Inglês, que adotava a teoria da irresponsabilidade das pessoas jurídicas, com o passar dos tempos, passou a ser mais flexível, punindo dessa forma os entes coletivos. Tal possibilidade se deu logo após a Idade Média, onde influenciada pelo direito romano, passou a punir grupos, mas nas figuras de famílias ou conjunto de pessoas. Foi quando em 1889, o Parlamento inglês aprovou um texto normativo onde considerava definitivamente a aplicação de sanções aos entes coletivos.

$\mathrm{O}$ ordenamento Americano seguiu à risca o sistema implantado no Direito Inglês, em um primeiro momento adotou a teoria da ficção, onde somente seus membros eram punidos, entretanto, passa-se à possibilidade de responsabilizar a pessoa jurídica pelos delitos que essa cometia, coincidência ou não, no mesmo período que na Inglaterra se fez. Mas é no início deste século que a Suprema Corte Americana ratifica de vez a punição aos entes coletivos.

Pela lição do renomado Shecaira, não podemos cogitar a existência, pelo menos até a edição da Constituição da República Federativa do Brasil de 1988, da responsabilização da pessoa jurídica, visto que o sistema jurídico que vigorou durante todo o período do Brasil Colônia foi o mesmo que existia em Portugal, ou seja, as Ordenações Reais, compostas pelas Ordenações Afonsinas (1446), Ordenações Manuelinas (1521) e, por último, fruto da união das Ordenações Manuelinas com as leis extravagantes em vigência, as Ordenações Filipinas, que nada mencionavam acerca de tal responsabilidade. ${ }^{221}$

\subsection{DIREITO COMPARADO}

É de extrema importância ressaltar que as legislações estrangeiras dividem-se quanto à responsabilização ou não da pessoa jurídica pela prática de crimes ambientais.

Os países que adotam o sistema Civil Law (o que basicamente significa dizer que as principais fontes do Direito adotadas são o texto da

\footnotetext{
${ }^{221}$ SHECAIRA, Sérgio Salomão. Responsabilidade penal da pessoa jurídica. São Paulo: Revista dos Tribunais, 1998. p. 23-39.
} 
lei), não costumam responsabilizar penalmente o ente coletivo. Já os que seguem o sistema jurídico do Common Law (que se baseiam mais na Jurisprudência que no texto da lei), admitem sanções às personalidades jurídicas, seguindo a orientação majoritária de rechaçar o princípio societas delinquere non potest (a sociedade não pode delinquir). Diante disso, a título de exemplo, os países que responsabilizam os entes coletivos são: Inglaterra, Holanda, Estados Unidos, Canadá, França, Dinamarca, China, México, Colômbia, Venezuela, Nova Zelândia e Austrália.

Em contrapartida os que não adotam tal instituto são: Alemanha, Espanha, Itália, Portugal, Bélgica, Suíça e Cuba.

Diante desse quadro, passa-se à análise desses institutos.

\subsubsection{Países adeptos à responsabilização}

O Direito Inglês que adota o instituto do Common Law, além de ter diversos julgados condenando entes jurídicos, editou textos normativos no mesmo sentido. Foi influenciado num primeiro momento pela teoria da ficção, após a Revolução Industrial, onde diversos entes personificados começaram a praticar ilícitos. Com o surgimento do Interpretation Act em 1889, todos os delitos passaram a ser passíveis de punição, tanto para a pessoa natural, como para a pessoa jurídica. Atualmente, na Inglaterra, os entes coletivos são puníveis pelo cometimento de infrações penais.

Os doutrinadores holandeses, a partir do fim da década de 40, começaram efetivamente a se preocupar com os danos causados pelas pessoas jurídicas e o fizeram por meio de decretos. Em 1950 editaram a primeira lei que responsabilizava os entes coletivos por delitos econômicos. Mas é em 1976, com a modificação do Código Penal Holandês, que efetivamente passou-se a considerar os entes personificados no polo passivo das demandas.

Nos Estados Unidos, desde o século XIX, vem se admitindo a responsabilização dos entes personificados. Entretanto não são todos os Estados confederados deste país que adotam o instituto, a maioria sim, mas poucos como o Estado de Indiana relutam em seguir com a teoria da ficção.

Adepto ao sistema da Common Law, o Canadá, assim como os Estados Unidos, prevê a responsabilidade penal das corporações pela 
prática de delitos, instituto esse previsto na lei sobre a qualidade do ambiente.

O Direito Francês é pautado por ser extremamente favorável à responsabilização penal do ente coletivo e os fundamentos invocados para justificar essa admissão, segundo a exposição dos motivos do Código Penal Francês, é de que a realidade criminológica mostra que as pessoas jurídicas dispõem de meios poderosos e podem estar na origem de atentados graves à saúde pública, ao ambiente, à ordem econômica e social, sendo certo que sua imunidade surge como algo grotesco no plano da equidade e da legalidade social.

Foi no pós-guerra, com o Código Penal de 1930 que a Dinamarca temporariamente começou a impor sanções penais às corporações que tivessem qualquer vínculo com o exército alemão. Posteriormente, com o fim da guerra, tal ordenamento foi revogado, mas uma série de leis e decretos passou a permitir a responsabilização aos entes coletivos. É de suma importância ressaltar que na Dinamarca a responsabilidade penal das pessoas jurídicas é facultativa, ficando a cargo do Ministério Público intentar ação em face do representante legal (pessoa física), da empresa (pessoa jurídica) ou de ambos.

Apesar da China, fidelíssima que é ao sistema socialista, afirmar que os entes coletivos têm o mesmo interesse do Estado, ou seja, o bem comum de todos, passou a punir as pessoas jurídicas pela prática de crimes econômicos.

Já no tocante a América Latina, temos o México que prevê em seu código uma sanção mais administrativa do que propriamente penal, pois prevê como punição a suspensão ou dissolução da sociedade empresária.

Tanto na Colômbia, como na Venezuela, seus ordenamentos penais consagraram a imputabilidade dos entes coletivos.

E para concluir nossa abordagem, na Oceania, países como Nova Zelândia e Austrália, adeptos ao Common Law, também consideram a possibilidade da pessoa jurídica figurar no polo passivo de uma ação penal por cometer delitos ambientais. ${ }^{222}$

222 SOUSA, Gaspar Alexandre Machado de. Crimes Ambientais - Responsabilidade Penal das Pessoas Jurídicas. 2 ed. AB Editora, 2007. p. 53-65. 


\subsubsection{Países contrários à responsabilização}

No Direito Alemão prevalece o princípio da irresponsabilidade e, por conta disso, a Alemanha tem um vasto direito administrativo criminal, já que prevalece a responsabilidade individual. Até o século XVIII, a Alemanha previa a responsabilidade penal das pessoas jurídicas, mas foi em 1953, em um congresso bienal, que os juristas alemães defenderam uma tese pela não responsabilização, o que se prolongou até os dias atuais.

O Código Penal Espanhol de 23 de novembro de 1995, instituído pela Lei Orgânica $n .^{\circ} 10$, vigente até hoje, prevê expressamente em seu artigo $5^{\circ}$ a responsabilidade pessoal do administrador de uma pessoa jurídica, ou seja, o Direito Espanhol desconhece a responsabilidade penal dos entes coletivos, onde a legislação penal e a jurisprudência espanhola entendem ser perfeitamente possível a individualização das pessoas físicas que se infiltram em corporações para a finalidade de praticar delitos, adotando assim o princípio da responsabilidade individual.

No Direito Italiano, em sede constitucional estabelecido pelo artigo 27, vigora o princípio da irresponsabilidade do ente coletivo, que estabelece que o ser humano é o único capaz de figurar no polo passivo de uma demanda.

O Direito Português, como regra geral, não admite a responsabilização penal dos entes coletivos. Embora a reforma penal de 1982 tenha consagrado a responsabilidade penal somente das pessoas físicas, excepcionalmente em alguns casos, a pessoa jurídica tem sido passível de punição, e esse é um entendimento que vem tomando conta da jurisprudência, apesar da grande maioria dos doutrinadores serem contrários, sob o argumento da noção de culpabilidade. Entretanto tudo nos leva a crer que essa resistência cairá por terra devido à recomendação do conselho da Europa de que seja reconhecida a responsabilidade penal das pessoas jurídicas.

De forma semelhante ao previsto na Itália, o ordenamento Belga prima pela irresponsabilidade da pessoa jurídica, entretanto se uma pessoa física for condenada ao pagamento de uma pena de multa e caso essa pessoa seja vinculada a algum ente coletivo, esse poderá responder de forma solidária com aquela. ${ }^{223}$

${ }^{223}$ SHECAIRA, Sérgio Salomão. Responsabilidade penal da pessoa jurídica. p. 64. 
O Código Penal da Suíça, de 1942, assim como o Espanhol, prevê que apenas os representantes legais dos entes coletivos podem ser punidos pela prática de delitos, portanto seguem o princípio da responsabilização individual.

Em Cuba, previa-se a responsabilidade penal dos entes coletivos até a revolução, onde daí por diante, instituído pelo Estado socialista, passou-se a considerar a responsabilidade penal somente para a pessoa natural. $^{224}$

\section{PRINCÍPIOS FUNDAMENTAIS DO DIREITO AMBIENTAL}

A Constituição Federal de 1988, ao prever em seu bojo a proteção ao meio ambiente, elevou-o à categoria de Direito Humano Difuso ou Coletivo, pois seu titular não é o indivíduo, tampouco a sociedade, mas sim todos os seres humanos, que têm direito a um meio ambiente ecologicamente equilibrado.

Dessa forma, pode-se, com base na obra do autor Paulo Affonso Leme Machado, citar alguns princípios do Direito Ambiental que asseguram a proteção ao meio ambiente, a saber:

Princípio do Acesso Equitativo aos Recursos Naturais

Por esse princípio, o meio ambiente é pensado como um bem de uso comum do povo. O ar, a água e o solo devem satisfazer às necessidades comuns de todos os habitantes da terra. Nessa tare$\mathrm{fa}$, o direito ambiental deve estabelecer normas que indiquem como verificar as necessidades de uso dos recursos ambientais, estabelecendo concomitantemente a utilização razoável ou necessária desse uso, ainda que os bens não sejam atualmente escassos. A equidade dará oportunidades iguais diante de casos iguais ou semelhantes. É na equidade que se encontra uma dimensão temporal capaz de assegurar às gerações futuras o uso dos recursos ambientais.

224 SOUSA, Gaspar Alexandre Machado de. Crimes Ambientais - Responsabilidade Penal das Pessoas Jurídicas. p. 65-68. 


\section{Princípios do Usuário-Pagador e do Poluidor-Pagador}

Para o autor, o princípio do poluidor-pagador está contido no do usuário-pagador. Este, portanto, é mais amplo, por significar que todo aquele que utiliza do recurso deve suportar o conjunto dos custos destinados a tornar possível a utilização do recurso e os custos advindos de sua própria utilização. Esse princípio tem por objetivo fazer com que esses custos não sejam suportados nem pelos poderes públicos, nem por terceiros, mas pelo utilizador.

\section{Princípio da Precaução}

O referido princípio contém o princípio da prevenção. A precaução contém um sentido mais amplo que a prevenção. A atitude de prevenir a degradação do meio ambiente é concepção que passou a ser aceita no mundo jurídico, especialmente nas três últimas décadas, graças, especialmente, ao Direito alemão que, desde a década de 70, o coloca ao lado do princípio da cooperação e do princípio do poluidor-pagador. A principal característica do princípio da precaução é a incerteza do dano ambiental, em que a atitude ambientalista deflui não só do que nós sabemos, mas também do que nós deveríamos ter sabido e, ainda, do que nós deveríamos duvidar. O fundamento da precaução, assim, decorre do risco ou da ameaça, que serão analisados conforme o setor que puder ser atingido pela atividade ou obra projetada. Dele decorre a obrigatoriedade do controle de risco para a vida, a qualidade de vida e o meio ambiente. Ou seja, o gerenciamento de riscos na modernidade é intrínseco à questão ambiental. Isso exige a implementação imediata das medidas de prevenção, não havendo espaço para qualquer forma de adiamento. Ainda, devido ao princípio da precaução, é obtida a inversão do ônus da prova em face da incerteza científica sobre a relação de causalidade, que necessariamente terá que ser presumida para que se logre o objetivo de evitar a ocorrência do dano. 


\section{Princípio da Prevenção}

O autor não faz uma distinção suficiente entre prevenção e precaução. Todavia, de suas ideias permite-se concluir que se refere à prevenção como o dever jurídico de evitar os danos ao meio ambiente, enquanto o princípio da precaução contém um espectro de atuação mais amplo, que incide sobre toda a atividade estatal.

\section{Princípio da Reparação}

Tal princípio determina que os danos ambientais sejam reparados, independentemente da discussão de culpa civil.

\section{Princípio da Informação}

A informação serve para o processo de educação de cada pessoa e da comunidade. Mais que isso, através dela é dada chance à pessoa informada de tomar posição e pronunciar-se sobre a matéria informada. Assim, a informação em tema ecológico é instrumento capaz de conferir ao indivíduo atitudes que possibilitem a preservação do meio ambiente e assegurem o acesso a essas informações, bem como a divulgação ampla das informações adequadas à satisfação dos fins perseguidos.

\section{Princípio da Participação}

Através desse, a conservação do meio ambiente é remetida a um quadro mais amplo, no qual a participação popular é devida em tema ambiental, diante dos interesses difusos e coletivos que o tema contém. Isso só será possível através de meios que garantam a possibilidade de cada cidadão de participar no processo de tomada de decisões, sendo que dessa forma o indivíduo sai de uma situação passiva de mero beneficiário, passando a partilhar da responsabili- 
dade na gestão dos interesses de toda a coletividade. Essa participação coletiva deve vir assegurada nas decisões administrativas, nos recursos administrativos, nos julgamentos administrativos, nas ações judiciais ambientais e, fundamentalmente, é preciso instituir um plebiscito ambiental para a efetiva manifestação popular com poder decisório no plano regional e nacional.

\section{Princípio do Desenvolvimento Sustentável}

Segundo a Comissão Mundial sobre Meio Ambiente e Desenvolvimento, desenvolvimento sustentável é aquele que atende às necessidades do presente sem comprometer as necessidades de as gerações futuras atenderem às suas próprias necessidades. Tal princípio pode ser entendido como um conjunto de medidas preventivas que podem alterar as condutas práticas da sociedade, visando o bem-estar da mesma. De acordo com esse princípio, deve haver uma exploração das atividades econômicas; porém, dentro dos limites oferecidos pelo meio ambiente e seus recursos naturais, de forma que sejam garantidos às gerações futuras todos esses recursos.

\section{Estudo Prévio de Impacto Ambiental}

O estudo prévio de impacto ambiental deve ser realizado antes da instalação de indústrias, devendo ser realizados estudos especiais e a avaliação do impacto. O artigo $225, \S 1^{\circ}$, VI, da Constituição Federal de 1988, determina que cabe ao poder público exigir, na forma da lei, o presente estudo de impacto ambiental. Vale ressaltar que o empreendedor responde com o seu patrimônio pelos erros e omissões do estudo de impacto ambiental e de seu relatório civilmente (Resolução - CONAMA, 237/97), também responderá criminalmente pela inidoneidade na elaboração do estudo prévio de impacto ambiental ou de qualquer outro documento em que informe à administração pública, sendo que os técnicos que desenvolvem o trabalho responderão de forma subjetiva, ou seja, mediante comprovação de dolo ou culpa. 
Função Social da Propriedade

O princípio da função social da propriedade é tratado pela Constituição Federal de 1988 no artigo 5, XXII e XXIII. A propriedade, seja ela privada ou pública, na área urbana ou rural, deve obedecer ao uso racional da propriedade e dos recursos naturais que lhes são integrantes. O artigo 182, $\S 2^{\circ}$ da Constituição Federal de 1988, determina que a propriedade urbana cumpre a função social da propriedade quando atender às diretrizes básicas estabelecidas no plano diretor obrigatório de cada cidade com mais de 20.000 (vinte mil) habitantes. Já a propriedade rural, de acordo com o artigo 186, também da Constituição Federal de 1988, atenderá à função social da propriedade quando utilizar adequadamente os recursos naturais disponíveis, preservar o meio ambiente, observar as disposições relativas às relações de trabalho. ${ }^{225}$

\section{MEIO AMBIENTE: UM BEM JURIDICAMENTE RELEVANTE}

No início, o meio ambiente foi muito pouco afetado. Não que o homem primitivo tivesse consciência acerca da importância de sua conservação; pelo contrário, ocorre, porém, que as suas necessidades eram bastante reduzidas e não causavam grande impacto no ambiente.

Com o surgimento da Revolução Industrial, alavancado por um rápido crescimento econômico mundial, é que se pode verificar as reiteradas agressões ao meio ambiente.

Apesar de ter propiciado uma melhoria nas condições gerais de vida, reduzindo dentre outros, a taxa de mortalidade, em contrapartida causou graves problemas sociais, como o crescimento desenfreado da indústria e da população, o que ocasionou um aumento considerável na degradação do meio ambiente.

225 MACHADO, Paulo Affonso Leme. Direito ambiental brasileiro. 13 ed. São Paulo: Malheiros, 2005. p. 80-86 
Foi nesse período, após diversas tragédias ambientais, que se percebeu a necessidade de proteger o meio ambiente. Tal proteção visava, num primeiro momento, apenas garantir interesses privados ou públicos particulares, regulando a título de exemplo, o direito de vizinhança e as formas de utilização da água.

Foi somente após o advento da 2. ${ }^{\mathrm{a}}$ Guerra Mundial é que se pôde perceber uma legislação mais eficaz e mais ampla para tutelar esse bem de extrema importância para a humanidade.

Em 10 de dezembro de 1948, foi aprovada a Declaração Universal dos Direitos do Homem, reconhecendo os direitos fundamentais do ser humano.

Posteriormente surgiram os direitos de primeira e segunda geração (direitos individuais e sociais) e os de terceira geração (direitos difusos e coletivos), no qual está inserido o direito de viver num meio ambiente ecologicamente equilibrado.

Foi com a Declaração da Conferência das Nações Unidas, realizada em Estocolmo, Suécia, de 5 a 16 de junho de 1972, que o meio ambiente foi elevado à categoria de "direito fundamental do homem".

Após a conferência de 1972, várias outras ocorreram, só que com menor repercussão. A que se destacou e reflete o ordenamento jurídico mundial, quando o quesito é meio ambiente, foi a Conferência de 1992, realizada no Rio de Janeiro, comumente conhecida como "RIO 92", que pôde contar com vários líderes de diversos países para a elaboração de um documento contendo vinte e sete princípios ambientais tendo por base a orientação de um desenvolvimento sustentável no planeta.

A seguir, surge a Declaração de Princípios sobre Florestas e a Convenção sobre a Biodiversidade, que pôde contar com o comprometimento de cento e doze países. Logo após, é marcada uma Convenção sobre o Clima, na qual se demonstra a preocupação em preservar o equilíbrio ambiental pelo seu número de adeptos; cento e cinquenta e dois países.

Teve como marco final, a Agenda 21 que, com um plano de ação internacional, propôs, dentre outros assuntos, a cooperação dos países no sentido de preservar os recursos hídricos, o ar, o solo, as florestas, os índios, as mulheres e os jovens. 
Desta forma, ao olharmos para os textos de várias Constituições, até mesmo o da nossa, nota-se o quão influenciados foram por essas Declarações e Convenções Internacionais. ${ }^{226}$

\section{A RESPONSABILIDADE PENAL DA PESSOA JURÍDICA NOS CRIMES AMBIENTAIS}

Como já mencionado anteriormente, a Constituição Federal de 1988 foi clara ao dispor em seus artigos $173 \S 5^{\circ}$ e $225 \S 3^{\circ}$ a responsabilidade dos entes coletivos.

Apesar de expressamente pautado na Carta Magna, o tema gerou controvérsia e polêmica entre os doutrinadores pátrios. A maior parte dos renomados constitucionalistas e penalistas do país afirmam vigorar o brocardo societas delinquere non potest (a sociedade não pode delinquir), outros, todavia, defendem que a Constituição Federal trouxe em seu texto a responsabilidade penal das pessoas jurídicas.

Diante desse quadro, Cappelli afirma que a "Lei Maior previu a responsabilidade penal das pessoas jurídicas" 227 . Para a autora, entender que o artigo $225 \S 3^{\circ}$ veio apenas afirmar a responsabilidade das pessoas físicas é considerá-lo inútil, devido à desnecessidade de tal texto no âmbito constitucional.

Contrário a tal posicionamento, Prado é um dos penalistas que de forma veemente negam que a Carta de 1988 tenha conferido tal responsabilização. Segundo o autor, o artigo $225 \S 3^{\circ}$ faz referência de condutas à pessoa física e de atividades à pessoa jurídica, demonstrando que o legislador procurou fazer tal discrepância ${ }^{228}$.

226 SOUSA, Gaspar Alexandre Machado de. Crimes Ambientais - Responsabilidade Penal das Pessoas Jurídicas. p. 107-111.

227 CAPPELLI, Sílvia. Responsabilidade penal da pessoa jurídica em matéria ambiental: uma necessária reflexão sobre o disposto no art. 225 , parágrafo $3 .^{\circ}$, da Constituição Federal. São Paulo: Revista dos Tribunais, 1996. p. 104.

${ }^{228}$ PRADO, Luiz Regis. Direito penal ambiental: problemas fundamentais. São Paulo: Revista dos Tribunais, 1992. p. 32. 
Já Coelho, seguindo esse mesmo entendimento, vai mais longe ao afirmar que o $\S 3^{\circ}$ do artigo 225 relaciona sanções penais às pessoas físicas e sanções administrativas às pessoas jurídicas. ${ }^{229}$

Com relação ao $\S 5^{\circ}$ do artigo 173 da Constituição Federal de 1988, Cernicchiaro afirma que "se fosse propósito do constituinte definirse quanto ao tema, evidentemente tê-lo-ia feito de maneira explícita, considerados o relevo e a polêmica da matéria, no capítulo que definiu os princípios do Direito Penal". 230

Porém, os referidos autores agiram falaciosamente ao pronunciarem tais posicionamentos, pois assim como afirma Branco:

Não há dúvida de que o propósito dos dispositivos constitucionais foi o de determinar que as pessoas jurídicas, independentemente da responsabilidade individual de seus dirigentes, incorram, também, numa responsabilização civil, administrativa ou penal, pelos atos praticados contra a ordem econômica e financeira e a economia popular e contra o meio ambiente. ${ }^{231}$

A título de sanar dúvidas quanto a responsabilização penal das pessoas jurídicas nos crimes ambientais, o ilustríssimo desembargador do Tribunal de Justiça do Estado de São Paulo, Freitas, trouxe em seu livro diversos julgados que demonstram a tendência dos juizados com relação ao tema:

Crime ambiental. Inconstitucionalidade do art. $3^{\circ}$ da Lei $\mathrm{n}^{\circ}$ 9.605/98. Inocorrência. Responsabilidade penal da pessoa jurídica. Admissibilidade (voto vencedor). $\mathrm{O}$ art. $3^{\circ}$ da Lei $\mathrm{n}^{\circ}$ 9.605/98 não é inconstitucional, pois a Constituição Federal autoriza a punição penal de empresas agressoras do meio ambiente (voto vencedor). (TACRIM. Mandado de

${ }^{229}$ COELHO, Walter. Teoria geral do crime. 2 ed. Porto Alegre: Sergio Antônio Fabris Editor, 1998. p. 48.

${ }^{230}$ CERNICCHIARO, Luiz Vicente; COSTA JR., Paulo José da. Direito penal na constituição. 3 ed. São Paulo: Revista dos Tribunais, 1995. p. 160.

${ }^{231}$ BRANCO, Fernando Castelo. A pessoa jurídica no processo penal. São Paulo: Saraiva, 2001. p. 59. 
Segurança $n^{\circ}$ 349.440/8, São Paulo, $3^{\text {a }}$ Câmara, j. 1/2/00, Rel. Juiz Fábio Gouvêa).

Crime contra o meio ambiente. Denúncia. Peça acusatória oferecida contra pessoa jurídica. Admissibilidade. Responsabilidade penal da pessoa jurídica prevista no ordenamento jurídico pátrio. Inteligência do art. $225, \S 3^{\circ}$, da CF e art. $3^{\circ}$ da Lei $n^{\circ}$ 9.605/98. (TJRS. Rel. Des. José Eugênio Tedesco. RDA 38/301).

Ação Penal. Crime contra o meio ambiente. Demanda interposta contra empresa em razão de ação ou omissão decorrente de decisão de seu representante legal ou contratual. Admissibilidade. Responsabilidade penal da pessoa jurídica prevista nos arts. 225, $\S 3^{\circ}$, da CF e $3^{\circ}$ da Lei ${ }^{\circ}$ 9.605/98.

Ementa oficial: A responsabilidade penal das pessoas jurídicas está prevista no art. $225, \S 3^{\circ}$, da $\mathrm{CF}$, bem como no art. $3^{\circ}$ da Lei ${ }^{\circ} 9.605 / 98$. Assim, podem figurar no pólo passivo de ação penal pela prática de crime ambiental, por ação ou omissão decorrente de seu representante legal ou contratual. (MS 2005.04.01.006368-5-SC. 7 ${ }^{\mathrm{a}}$ T., j. 10/5/05. Rel. Des. Federal Tadaqui Hirose. DJU 25/5/05). ${ }^{232}$

Ante o exposto, é possível afirmar que a responsabilidade criminal das pessoas jurídicas foi realmente consagrada no texto da Lei Maior brasileira. Todavia, por constituir exceção à regra da responsabilidade penal das pessoas naturais, o referido instituto deve ser aplicado somente nas hipóteses autorizadas expressamente pelos dispositivos constitucionais. $^{233}$

\section{PENAS APLICÁVEIS À PESSOA JURÍDICA}

\footnotetext{
232 FREITAS, Gilberto Passos de. Crimes ambientais: jurisprudência organizada. Campinas: Millennium, 2006. p. 47.

233 SOUSA, Gaspar Alexandre Machado de. Crimes Ambientais - Responsabilidade Penal das Pessoas Jurídicas. p. 76.
} 
Primeiramente, antes de abordarmos as penas cabíveis à pessoa jurídica, faz-se mister indagarmos se além do ente coletivo de direito privado, poderia o de direito público (Estado), figurar no polo passivo de uma ação penal. Nosso legislador pátrio por não ter feito menção alguma, fez surgir entre os doutrinadores mais esse debate, se deve ou não ser punido o Estado frente ao cometimento de delitos ambientais?

Entendemos não ser cabível a punição do Estado, visto que a sua finalidade é a de melhor atender aos anseios da coletividade e que em nada lucraria se cometesse ilícitos ambientais, a não ser é claro se provado a responsabilidade de seu administrador, onde somente esse seria responsabilizado. Além do mais, seria redundante a aplicação de sanções ao Estado, por exemplo: no caso de a União ser condenada a prestação de serviços à comunidade, isso não teria lógica alguma visto que é dever da União prestá-los independentemente. Além do mais o Código Penal francês de 1994, que serviu de base para nosso constituinte, exclui taxativamente essa possibilidade.

Superado essa problemática, passamos ao estudo das sanções cabíveis a pessoa jurídica, que são de acordo com o artigo 21 da Lei n. ${ }^{\circ}$ 9.605/98: multa; restritivas de direitos; e, prestação de serviços à comunidade.

A pena de multa está prevista no artigo 18 da Lei n. ${ }^{\circ}$ 9.605/98 que assim disciplina: "A multa será calculada segundo os critérios do Código Penal; se revelar-se ineficaz, ainda que aplicada no valor máximo, poderá ser aumentada até três vezes, tendo em vista o valor da vantagem econômica auferida".

E ainda, o artigo $6^{\circ}$ da referida lei prevê que "para imposição e gradação da penalidade, a autoridade competente observará: III - a situação econômica do infrator, no caso de multa." Assim diante do lucro advindo de seu ilícito penal é que se chegará a um valor justo a ser aplicado na forma de pena de multa.

Com relação às penas restritivas de direitos aplicáveis à pessoa jurídica temos:

I - suspensão parcial ou total de atividades: "a suspensão de atividades será aplicada quando estas não estiverem obedecendo às disposições legais ou regulamentares, relativas à proteção do meio ambiente." (artigo 22, I e $\S 1^{\circ}$ )

II - interdição temporária de estabelecimento, obra ou atividade: "a interdição será aplicada quando o estabelecimento, obra ou atividade 
estiver funcionando sem a devida autorização, ou em desacordo com a concedida, ou com violação de disposição legal ou regulamentar." (artigo 22 , II e $\S 2^{\circ}$ )

III - proibição de contratar com o Poder Público, bem como dele obter subsídios, subvenções ou doações: "a proibição de contratar com o Poder Público e dele obter subsídios, subvenções ou doações não poderá exceder o prazo de dez anos." (artigo 22 , III e $\S 3^{\circ}$ )

IV - prestação de serviços à comunidade (que por força do artigo 43, inciso IV do Código Penal deve ser entendido como espécie do gênero "restritivas de direitos") que consistirá em: "custeio de programas e de projetos ambientais, execução de obras de recuperação de áreas degradadas, manutenção de espaços públicos e contribuições a entidades ambientais ou culturais públicas.” (artigo 23)

Vale ressaltar que para alguns ambientalistas a liquidação forçada, prevista no artigo 24 da lei, também é tida como uma sanção penal aplicável exclusivamente para a pessoa jurídica, mas não para aquela que eventualmente cometa esse delito, mas para aquela que tenha como atividade preponderante a prática de crimes ambientais, por exemplo: madeireira clandestina e pesqueiro ilegal. Como consequência, a liquidação forçada gera a extinção da pessoa jurídica, porque todo o seu patrimônio será considerado como instrumento de crime e consequentemente confiscado para o Fundo Penitenciário Nacional.

\section{ASPECTOS FAVORÁVEIS À RESPONSABILIZAÇÃO}

Vários penalistas defendem que a Constituição Federal prevê a penalização das pessoas jurídicas, outros indo de encontro ao princípio da supremacia constitucional rechaçam a ideia, entretanto assim consagrou nossa Carta Magna:

Art. 173 (omissis)

$\S 5^{\circ}$ A lei, sem prejuízo da responsabilidade individual dos dirigentes da pessoa jurídica, estabelecerá a responsabilidade desta, sujeitando-a às punições compatíveis com sua natureza, nos atos praticados contra a ordem econômica e financeira e contra a economia popular. 
Art. 225- Todos têm direito ao meio ambiente ecologicamente equilibrado, bem de uso comum do povo e essencial à sadia qualidade de vida, impondose ao Poder Público e à coletividade o dever de defendê-lo e preservá-lo para as presentes e futuras gerações.

$\S 3^{\circ}$ As condutas e atividades consideradas lesivas ao meio ambiente sujeitarão os infratores, pessoas físicas ou jurídicas, a sanções penais e administrativas, independentemente da obrigação de reparar os danos causados.

Os argumentos levantados são de que os entes coletivos agem de forma independente por possuírem vontade e patrimônios próprios, distintamente de seus administradores ou sócios.

Defendem que a flexibilização da pena é admitida para as pessoas físicas, como a aplicação de multa, e que a mesma flexibilização deveria atingir as pessoas jurídicas.

Que questões como imputabilidade penal e personalização das penas estariam superadas por entenderem que os entes coletivos são dotados de consciência. ${ }^{234}$

E que a aplicação de penas civis e administrativas não deve obstar a aplicação de sanções penais, visto que aquelas têm caráter de reparação, e esta de punição.

Portanto, concluem que pelo fato dos entes personificados terem vontade própria para cometerem delitos e consciência disso, visando muitas vezes a satisfação de interesses próprios, seria possível figurarem no polo passivo de uma ação penal.

\section{ASPECTOS DESFAVORÁVEIS À RESPONSABILIZAÇÃO}

O já mencionado $\S 3^{\circ}$ do artigo 225 da nossa Carta Magna nos leva a crer na possibilidade de aplicação de sanções civis, administrativas

\footnotetext{
${ }^{234}$ SANCTIS, Fausto Martin de. Responsabilidade penal da pessoa jurídica. São Paulo: Saraiva, 1999. p. 41-42
} 
e penais tanto para pessoa física quanto para a jurídica, entretanto a imputabilidade penal é de caráter estritamente humano. ${ }^{235}$

A Constituição Federal em seu artigo $5^{\circ}$, inciso XLVI, adota as seguintes espécies de pena: a) privação ou restrição da liberdade; b) perda de bens; c) multa; d) prestação social alternativa e e) suspensão ou interdição de direitos.

De acordo com tal preceito, com exceção da alínea "a", que é voltada exclusivamente à pessoa natural, perda de bens, multa, prestação social alternativa e penas restritivas de atividade (suspensão ou interdição de direitos) são passíveis de aplicação em face tanto da pessoa física quanto da jurídica. Entretanto a própria Constituição no $\S 5^{\circ}$ do artigo 173, veda a possibilidade da pessoa jurídica figurar como ré.

Assim, de acordo com o artigo $5^{\circ}$, inciso XLV da Lei Maior, que trata do princípio da personalidade da pena, a sanção penal estaria somente ligada à pessoa física: "nenhuma pena passará da pessoa do condenado, podendo a obrigação de reparar o dano e a decretação do perdimento de bens ser, nos termos da lei, estendidas aos sucessores e contra eles executadas, até o limite do valor do patrimônio transferido".

Se desrespeitado o artigo supra, estaria indo de encontro também ao princípio da isonomia (Constituição Federal, art. $5 .^{\circ}$, caput), que prevê: "Todos são iguais perante a lei, sem distinção de qualquer natureza, garantindo-se aos brasileiros e aos estrangeiros residentes no País a inviolabilidade do direito à vida, à liberdade, à igualdade, à segurança e à propriedade..."

Dessa forma, se verificado que realmente a pessoa jurídica foi quem praticou o delito, seus administradores (partícipes) poderiam se beneficiar de alguma maneira nas investigações policiais.

Uma questão a ser resolvida seria a do local do crime $(\mathrm{CP}$, art. $6^{\circ}{ }^{\circ}$. Se a empresa ré estiver espalhada pelo território nacional, quais administradores deveriam ser responsabilizados?

Outro preceito legal que restaria prejudicado seria o da ação de regresso previsto no $\S 6^{\circ}$ do art. 37 da Constituição Federal: "As pessoas jurídicas de direito público e as de direito privado prestadoras de serviços públicos responderão pelos danos que seus agentes, nessa qualidade, cau-

235 PRADO, Luiz Regis. Responsabilidade penal da pessoa jurídica: em defesa do princípio da imputação penal subjetiva. São Paulo: Revista dos Tribunais, 2001. p. 150. 
sarem a terceiros, assegurado o direito de regresso contra o responsável nos casos de dolo ou culpa".

Faltaria legitimidade para impetrar a ação regressiva, pois um réu (no caso a pessoa jurídica) não poderia promover contra um corréu (pessoa física - administrador do ente coletivo) uma ação de reparação de danos oriunda de um fato típico, ilícito e culpável que ambos cometeram.

Algo defendido pelos penalistas contrários à aplicação de sanções penais à pessoa jurídica está relacionado à culpabilidade, prevista no artigo 29 do Código Penal, tais penalistas levantam questões do tipo: Como medir o grau de participação das pessoas jurídicas? A quem o Delegado de Polícia deve encaminhar uma intimação? Dentre outras indagações.

Assim não há nenhum artigo do Código Penal que faça menção a penalizações à pessoa jurídica, pois em nosso ordenamento foi consagrado sanções de caráter penal somente às pessoas naturais. Dessa forma, pesa contra a responsabilização penal dos entes coletivos os seguintes argumentos: de que o ente coletivo não tem vontade própria, somente medidas administrativas são aplicáveis, que as penas impostas a pessoa jurídica poderia atingir sócios inocentes, somente o homem tem animus para praticar um ato delituoso, se o objetivo maior das sanções penais é o da recuperação do agente, o que não aconteceria no caso dos entes personificados.

\section{CONSIDERAÇÕES FINAIS}

As sanções civis e administrativas demonstraram-se ineficazes ao combate das lesões sofridas pelo meio ambiente no decorrer dos tempos, pois mesmo com a aplicação de sanções do tipo indenizatórias (sempre limitadas ao valor da reparação do dano causado), o ente coletivo ainda obtinha vantagens econômicas com a prática de seus crimes, demonstrando assim a ineficácia destas penalidades. Algo notório é que as empresas através de grupamentos de pessoas valiam-se desta "fachada", agindo no ocultismo e na impunidade, para cometer descaradamente delitos na esfera ambiental no intuito de obter cada vez mais lucro.

Foi dessa forma que se procurou justificar a ingerência da proteção penal, se a utilização de todos os meios jurídicos na esfera civil e administrativa não foram suficientes para tutelar o bem em questão, deve- 
se procurar um que o faça, e nada melhor que o direito penal que de forma coercitiva vem apresentando resultados significativos.

A Constituição Federal de 1988, dentre várias inovações, previu um capítulo próprio ao meio ambiente, elevando tal bem a uso comum do povo. Para dar a real efetividade a esse preceito constitucional surgiu a Lei n ${ }^{\circ} 9.605$ de 12 de fevereiro de 1998, a "Lei de Crimes Ambientais", que trouxe em seu bojo vários avanços, alguns esperados, como o aumento de pena para alguns delitos, outros polêmicos, como a responsabilização criminal dos entes coletivos pela prática de crimes ambientais, criando dessa forma uma nova tutela ambiental, de modo a prevenir os danos causados ao meio ambiente frente às pessoas jurídicas, consideradas as maiores degradadoras da natureza.

Apesar das controvérsias geradas a partir da responsabilização penal do ente coletivo, sugerimos ao nosso legislador pátrio que acrescente ao Código Penal a possibilidade do ente coletivo ser punido na esfera penal, ou, crie meios hábeis dessa responsabilização se ater na esfera administrativa, devido ao caráter das sanções impostas, o que tomaria mais tempo devido o preceito em questão estar previsto em nossa Bíblia Política, e também na lei n..$^{\circ}$ 9.605/98.

Por enquanto, não resta dúvida que o ordenamento jurídico brasileiro enobreceu-se com louvável lei, dando uma resposta aos ânimos desta nação, que almeja uma efetiva proteção ao meio ambiente, livre de abusos produzidos pelo capitalismo desenfreado e devastador praticado pelas pessoas jurídicas.

\section{REFERÊNCIAS BIBLIOGRÁFICAS}

BRANCO, Fernando Castelo. A pessoa jurídica no processo penal. São Paulo: Saraiva, 2001.

BRASIL. Constituição da República Federativa do Brasil. Disponível em:

$<$

http://.pla

nalto.gov.br/ccivil_03/constituicao/constitui\%C3\%A7ao.htm>.

Acessado em: 22 de fev. de 2013.

. Decreto-Lei n. ${ }^{\circ}$ 2.848, de 07 de dezembro de 1940. Código

Penal.

Disponível

em:

$<$ https://www.planalto.gov.br/ccivil_03/Decreto-

Lei/del2848.htm>. Acessado em: 10 de mar. de 2013. 
. Lei n. ${ }^{\circ} 4.771$, de 15 de setembro de 1965. Código Florestal. Disponível em:<

http://www.planalto.gov.br/ccivil_03/Leis/L4771.htm>. Acessado em: 22 de fev. de 2013.

. Lei n. ${ }^{\circ}$ 5.197, de 03 de janeiro de 1967. Dispõe sobre a proteção à fauna e dá outras providências. Disponível em <http://www.planalto.gov.br/ccivil_03 /Leis /L51 97.htm>. Acessado em: 22 de fev. de 2013.

. Lei $\mathrm{n}^{\circ} 6.938$, de 31 de agosto de 1981. Dispõe sobre a Política Nacional do Meio Ambiente, seus fins e mecanismos de formulação e aplicação, e dá outras providências. Disponível em <http://www.planalto.gov.br/ccivil_03/leis/16938.htm>. Acessado em: 22 de fev. de 2013

. Resolução $\mathrm{n}^{\circ}$ 237, de 19 de dezembro de 1997. Disponível em:

http://www.mma.gov.br/port/conama/res/res97/res23797.html > Acessado em: 22 de fev. de 2013.

. Lei $n .^{\circ} 9.605$, de 12 de fevereiro de 1998. Dispõe sobre as sanções penais e administrativas derivadas de condutas e atividades lesivas ao meio ambiente, e dá outras providências. Disponível em: <http://www.planalto.gov.br/ ccivil_ 03/Leis/ L9605 .htm> Acessado em: 22 de fev. de 2013.

CAPPELLI, Sílvia. Responsabilidade penal da pessoa jurídica em matéria ambiental: uma necessária reflexão sobre o disposto no art. 225, parágrafo 3. ${ }^{\circ}$, da Constituição Federal. São Paulo: Revista dos Tribunais, 1996.

CERNICCHIARO, Luiz Vicente; COSTA JR., Paulo José da. Direito penal na constituição. 3 ed. São Paulo: Revista dos Tribunais, 1995.

COELHO, Walter. Teoria geral do crime. 2 ed. Porto Alegre: Sergio Antônio Fabris Editor, 1998.

FREITAS, Gilberto Passos de. Crimes ambientais: jurisprudência organizada. Campinas: Millennium, 2006.

LEMOS, Patrícia Fraga Iglecias. Direito Ambiental: Responsabilidade Civil e Proteção ao Meio Ambiente. 2 ed. São Paulo: Revista dos Tribunais, 2008.

MACHADO, Paulo Affonso Leme. Direito ambiental brasileiro. 13 ed. São Paulo: Malheiros, 2005. 
MATEO, Ramón Martín. Derecho Ambiental. Instituto de Estudio de Administración Local. Madrid, 1997.

PRADO, Luiz Regis. Direito penal ambiental: problemas fundamentais. São Paulo: Revista dos Tribunais, 1992.

Responsabilidade penal da pessoa jurídica: em defesa do princípio da imputação penal subjetiva. São Paulo: Revista dos Tribunais, 2001.

SANCTIS, Fausto Martin de. Responsabilidade penal da pessoa jurídica. São Paulo: Saraiva, 1999.

SHECAIRA, Sérgio Salomão. Responsabilidade penal da pessoa jurídica. São Paulo: Revista dos Tribunais, 1998.

SILVA, José Afonso da. Direito Ambiental Constitucional. 2 ed. São Paulo: Malheiros, 1995.

SOUSA, Gaspar Alexandre Machado de. Crimes Ambientais Responsabilidade Penal das Pessoas Jurídicas. 2 ed. AB Editora, 2007. 